\title{
Participatory Research Methods - Choice Points in the Research Process
}

\author{
Lisa M. Vaughn, $\mathrm{PhD}^{1}$ (1), Farrah Jacquez, $\mathrm{PhD}^{2}$ (1) \\ ${ }^{1}$ Cincinnati Children's Hospital Medical Center, ${ }^{2}$ Psychology, University of Cincinnati \\ Keywords: research engagement, community-based participatory research, research participation, research choice points model, participatory research methods, \\ participatory research \\ https://doi.org/10.35844/001c.13244
}

Journal of Participatory Research Methods

Vol. 1, Issue 1, 2020

\begin{abstract}
Participatory research (PR) encompasses research designs, methods, and frameworks that use systematic inquiry in direct collaboration with those affected by an issue being studied for the purpose of action or change. PR engages those who are not necessarily trained in research but belong to or represent the interests of the people who are the focus of the research. Researchers utilizing a PR approach often choose research methods and tools that can be conducted in a participatory, democratic manner that values genuine and meaningful participation in the research process. This article serves as an introduction to participatory research methods, including an overview of participatory research, terminology across disciplines, elements that make a research method participatory, and a model detailing the choice points that require decisions about which tools and methods will produce the desired level of participation at each stage of the research process. Intentional choices of participatory research methods, tools, and processes can help researchers to more meaningfully engage stakeholders and communities in research, which in turn has the potential to create relevant, meaningful research findings translated to action.
\end{abstract}

\section{Participatory Research}

Participatory Research (PR) is a research-to-action approach that emphasizes direct engagement of local priorities and perspectives (Cornwall \& Jewkes, 1995). PR can be defined as an umbrella term for research designs, methods, and frameworks that use systematic inquiry in direct collaboration with those affected by the issue being studied for the purpose of action or change (Cargo \& Mercer, 2008). PR prioritizes co-constructing research through partnerships between researchers and stakeholders, community members, or others with insider knowledge and lived expertise (Jagosh et al., 2012). Simply put, PR engages those who are not necessarily trained in research but belong to or represent the interests of the people who are the focus of the research. Instead of the "subjects" of traditional research, PR collaborates with stakeholders, community, constituents, and end-users in the research process.

By sharing leadership in research, PR "contributes directly to the flourishing of human persons, their communities, and the ecosystems of which they are part" (Reason \& Torbert, 2001, p. 6). PR has a multitude of benefits including research that is informed by and relevant to real-world contexts, results that can be more effectively translated into community and non-academic settings, and research quality and rigor that is improved by the "integration of researchers' theoretical and methodological expertise with nonacademic participants' realworld knowledge and experiences into a mutually reinforcing partnership" (Balazs \& Morello-Frosch, 2013; Bush et al., 2017; Cargo \& Mercer, 2008, p. 
327; International Collaboration for Participatory Health Research (ICPHR), 2013; Warren et al., 2018). Increasingly, PR is used and valued across disciplines as a way to solve complex problems; however, the nomenclature of the specific PR approaches varies widely. As can be seen in Table 1, the breadth of terms describing the PR orientation is vast, but they share in common a value in doing research with those who are typically the subjects of research, rather than on them (Reason \& Torbert, 2001). Table 1 is not intended to be an exhaustive list of the frameworks, approaches, and orientations that utilize PR, but it demonstrates that there are researchers within almost every discipline that view research as a collaborative inquiry process with research goals that go beyond knowledge generation and into real-world impact.

Over the last decade, researchers across disciplines have increasingly engaged all types of stakeholders, including consumers, end-users, patients, youth, and individuals from marginalized communities to have active roles in the research process, sharing decision-making to ensure research is relevant and translational in their lives (Vaughn et al., 2018). The way that these stakeholders are engaged is not conceptualized as a dichotomous distinction, but rather as a continuum ranging from academic-driven research to equitable shared decision making between academic and community partners. For example, a report from the National Institutes of Health describes communityengaged health research as a continuum with increasing involvement, impact, trust, and communication flow that ranges from outreach (i.e., researchers provide communities with information) to shared leadership (i.e., strong bidirectional partnership where final decision making is at the community level) (CTSA Community Engagement Key Function Committee Task Force on the Principles of Community Engagement, 2011). Key and colleagues (2019) describe research engagement as ranging from community informed to community driven. Similarly, from the field of civic engagement, the Spectrum of Public Participation describes a continuum of engagement ranging from inform, in which information is provided to the public to help communities understand a complex topic, to empower, in which decisions made by stakeholders are implemented into practice (International Association of Public Participation (IAP2), 2018). The terms and definitions differ in these three frameworks, but the implications for PR are the same: the choice of participation level is closely tied to the impact research will have in real world settings.

\section{Research Methods}

A research method is typically thought of as a means of data collection or data generation. Conventionally, research methods are categorized as quantitative methods (i.e., surveys, questionnaires), qualitative methods (i.e., interviews, focus groups), or some combination of the two in mixed methods research. Research methods vary considerably and can include written, visual, verbal, observational, arts-based, and active strategies. Within PR, the process of engaging people in each step of the research process includes tools, tasks, and structured activities that are used to facilitate participation, shared decision- 
Table 1: Participatory Research Frameworks, Orientations, and Approaches

\begin{tabular}{|c|c|c|c|}
\hline $\begin{array}{l}\text { Framework/ } \\
\text { Approach }\end{array}$ & Definition & Types/Variations & Key Sources \\
\hline $\begin{array}{l}\text { Action } \\
\text { Anthropology }\end{array}$ & $\begin{array}{l}\text { A process of social science research that combines inquiry } \\
\text { with practical solutions of day-to-day problems of a } \\
\text { particular group or community. }\end{array}$ & $\begin{array}{l}\text { applied action } \\
\text { anthropology; } \\
\text { collective action } \\
\text { anthropology }\end{array}$ & $\begin{array}{l}\text { Bennett (1996); Stull } \\
\text { (2019); Tax (1975) }\end{array}$ \\
\hline Action Inquiry & $\begin{array}{l}\text { An approach to learning and inquiry that combines } \\
\text { research and practice for the purpose of transformational } \\
\text { change; often applied to leadership practices. }\end{array}$ & $\begin{array}{l}\text { cooperative } \\
\text { inquiry; dialectical } \\
\text { inquiry }\end{array}$ & $\begin{array}{l}\text { Barnes-Najor (2019); } \\
\text { Torbert (2004) }\end{array}$ \\
\hline $\begin{array}{l}\text { Action } \\
\text { Learning }\end{array}$ & $\begin{array}{l}\text { A problem-solving approach that uses a process of action } \\
\text { and reflection. Commonly used in businesses and non- } \\
\text { profits and in governmental and educational settings. }\end{array}$ & $\begin{array}{l}\text { action reflection } \\
\text { learning; critical } \\
\text { action learning; } \\
\text { unlearning }\end{array}$ & $\begin{array}{l}\text { McGill \& Brockbank } \\
\text { (2003); Revans } \\
\text { (2011); Zuber- } \\
\text { Skerritt, Wood, \& } \\
\text { Kearney (2020) }\end{array}$ \\
\hline $\begin{array}{l}\text { Action } \\
\text { Research (AR) }\end{array}$ & $\begin{array}{l}\text { Represents a broad family of research approaches that } \\
\text { emphasize social change and transformation, active } \\
\text { collaboration through participation between researcher } \\
\text { and members of the system, and iterative cycles of action } \\
\text { and reflection to address practical concerns. }\end{array}$ & $\begin{array}{l}\text { arts-based AR; } \\
\text { critical AR; } \\
\text { feminist AR; first } \\
\text { person AR; } \\
\text { systematic AR }\end{array}$ & $\begin{array}{l}\text { Bradbury (2015); } \\
\text { Chandler \& Torbert } \\
\text { (2003); Lewin } \\
\text { (1946); Reason \& } \\
\text { Torbert (2001) }\end{array}$ \\
\hline Action Science & $\begin{array}{l}\text { An intervention approach used within organization } \\
\text { development to improve behavioral processes and } \\
\text { organizational effectiveness, encourage learning, and } \\
\text { create interpersonal, group, intergroup, or organization- } \\
\text { wide change. }\end{array}$ & $\begin{array}{l}\text { organization } \\
\text { development }\end{array}$ & $\begin{array}{l}\text { Argyris, Putnam, \& } \\
\text { Smith (1985); } \\
\text { Argyris (1995); } \\
\text { Friedman, Razer, \& } \\
\text { Sykes (2004). }\end{array}$ \\
\hline $\begin{array}{l}\text { Appreciative } \\
\text { Inquiry (AI) }\end{array}$ & $\begin{array}{l}\text { An asset-based approach based in the positive potential of } \\
\text { individuals, communities, and organizations that directly } \\
\text { engages stakeholders in positive social change around } \\
\text { what is already working rather than solving problems. }\end{array}$ & $\begin{array}{l}\text { appreciative } \\
\text { systems }\end{array}$ & $\begin{array}{l}\text { Cooperrider, } \\
\text { Whitney, Stavros, \& } \\
\text { Stavros (2008); Reed } \\
\text { (2007); Watkins, } \\
\text { Mohr, \& Kelly (2011) }\end{array}$ \\
\hline $\begin{array}{l}\text { Asset-Based } \\
\text { Community } \\
\text { Development } \\
\text { (ABCD) }\end{array}$ & $\begin{array}{l}\text { An approach to sustainable community-driven } \\
\text { development that posits communities can drive the } \\
\text { development process themselves by identifying and } \\
\text { mobilizing existing, but often unrecognized assets. }\end{array}$ & $\begin{array}{l}\text { citizen-led } \\
\text { development }\end{array}$ & $\begin{array}{l}\text { Mathie \& } \\
\text { Cunningham (2003); } \\
\text { Kretzmann \& } \\
\text { McKnight (1996) }\end{array}$ \\
\hline $\begin{array}{l}\text { Citizen } \\
\text { Science }\end{array}$ & $\begin{array}{l}\text { Research that is conducted at least in some degree by } \\
\text { members of the public; popularized in environmental } \\
\text { science }\end{array}$ & $\begin{array}{l}\text { public } \\
\text { participation in } \\
\text { science; crowd- } \\
\text { sourced science; } \\
\text { civic science }\end{array}$ & $\begin{array}{l}\text { Bonney, et al (2009); } \\
\text { Dickinson, et al } \\
\text { (2012); Shirk, et al } \\
\text { (2012) }\end{array}$ \\
\hline $\begin{array}{l}\text { Collaborative } \\
\text { Change } \\
\text { Research, } \\
\text { Evaluation, \& } \\
\text { Design } \\
\text { (CCRED) }\end{array}$ & $\begin{array}{l}\text { Collective term referring to participatory approaches } \\
\text { utilized by researchers, evaluators and designers who } \\
\text { bridge research and practice for positive social change }\end{array}$ & $\begin{array}{l}\text { collaborative } \\
\text { change research }\end{array}$ & $\begin{array}{l}\text { Busch, Jean- } \\
\text { Baptiste, Person, \& } \\
\text { Vaughn (2019) }\end{array}$ \\
\hline $\begin{array}{l}\text { Community- } \\
\text { Based } \\
\text { Participatory } \\
\text { Research } \\
\text { (CBPR) }\end{array}$ & $\begin{array}{l}\text { An orientation to research often focused on health-related } \\
\text { issues that equitably involves all partners, including } \\
\text { researchers and community members, in all phases of the } \\
\text { research process, from study design to dissemination. }\end{array}$ & $\begin{array}{l}\text { community } \\
\text { capacity; } \\
\text { participatory } \\
\text { health research; } \\
\text { community-based } \\
\text { participatory } \\
\text { action research }\end{array}$ & $\begin{array}{l}\text { Israel, Eng, Schulz, \& } \\
\text { Parker (2013); } \\
\text { Wallerstein, Duran, } \\
\text { Oetzel, \& Minkler } \\
\text { (2018); Wallerstein } \\
\text { \& Duran (2006) }\end{array}$ \\
\hline $\begin{array}{l}\text { Community- } \\
\text { Engaged } \\
\text { Research } \\
\text { (CEnR) }\end{array}$ & $\begin{array}{l}\text { Represents a broad array of research approaches that } \\
\text { emphasize academic-community partnerships focused on } \\
\text { issues that affect the well-being of the community of focus. }\end{array}$ & $\begin{array}{l}\text { community } \\
\text { engagement in } \\
\text { research }\end{array}$ & $\begin{array}{l}\text { Ahmed \& Palermo } \\
\text { (2010); CTSA (2011); } \\
\text { Key et al (2019) }\end{array}$ \\
\hline $\begin{array}{l}\text { Community } \\
\text { Science }\end{array}$ & $\begin{array}{l}\text { Research that is focused on building strong communities } \\
\text { through partnered prevention, treatment, education, and } \\
\text { health promotion efforts. Often used within community } \\
\text { psychology. }\end{array}$ & & $\begin{array}{l}\text { Chinman, et al } \\
\text { (2005); Luke (2005); } \\
\text { Wandersman (2003) }\end{array}$ \\
\hline $\begin{array}{l}\text { Decolonizing } \\
\text { Methodologies }\end{array}$ & $\begin{array}{l}\text { Research methods that question the assumptions of power } \\
\text { in the research process, in research relationships, and in } \\
\text { ways of knowing. Approaches that challenge traditional } \\
\text { Western methods that undermine lived experiences of } \\
\text { marginalized groups. }\end{array}$ & $\begin{array}{l}\text { indigenous } \\
\text { research } \\
\text { methodologies }\end{array}$ & $\begin{array}{l}\text { Chilisa (2019); Smith } \\
\text { (2013) }\end{array}$ \\
\hline
\end{tabular}
marginalized groups. 


\begin{tabular}{|c|c|c|c|}
\hline $\begin{array}{l}\text { Framework/ } \\
\text { Approach }\end{array}$ & Definition & Types/Variations & Key Sources \\
\hline $\begin{array}{l}\text { Educational } \\
\text { Action } \\
\text { Research }\end{array}$ & $\begin{array}{l}\text { Represents a broad range of action research conducted in } \\
\text { educational and school settings. }\end{array}$ & $\begin{array}{l}\text { teacher action } \\
\text { research }\end{array}$ & $\begin{array}{l}\text { Kinsler, K. (2010); } \\
\text { Mertler (2019); } \\
\text { Somekh (2009) }\end{array}$ \\
\hline $\begin{array}{l}\text { Emancipatory } \\
\text { Research }\end{array}$ & $\begin{array}{l}\text { Research that shifts power and control from researchers } \\
\text { to those who would be the research subjects. Often used in } \\
\text { the context of disability research. }\end{array}$ & $\begin{array}{l}\text { emancipatory } \\
\text { action research }\end{array}$ & $\begin{array}{l}\text { Oliver (1997); } \\
\text { Walmsley, J. (2001) }\end{array}$ \\
\hline $\begin{array}{l}\text { Health Impact } \\
\text { Assessment } \\
\text { (HIA) }\end{array}$ & $\begin{array}{l}\text { A structured method to understand health consequences } \\
\text { of projects and policies that takes into account those who } \\
\text { might be impacted by a proposed policy. }\end{array}$ & $\begin{array}{l}\text { community health } \\
\text { needs assessment }\end{array}$ & $\begin{array}{l}\text { Brigg (2008); Lock } \\
\text { (2000) }\end{array}$ \\
\hline $\begin{array}{l}\text { Participatory } \\
\text { Action } \\
\text { Research } \\
\text { (PAR) }\end{array}$ & $\begin{array}{l}\text { Combines participation and action to understand and } \\
\text { address societal issues. Emphasizes democratic processes } \\
\text { in participation with others rather than research for } \\
\text { research's sake conducted on people/communities. }\end{array}$ & $\begin{array}{l}\text { participatory } \\
\text { research; youth } \\
\text { participatory } \\
\text { action research }\end{array}$ & $\begin{array}{l}\text { Baum, MacDougall, } \\
\text { \& Smith (2006); } \\
\text { Cammarota \& Fine } \\
\text { (2010); Chevalier \& } \\
\text { Buckles (2019); Ozer } \\
\text { (2017) }\end{array}$ \\
\hline $\begin{array}{l}\text { Participatory } \\
\text { Evaluation }\end{array}$ & $\begin{array}{l}\text { An approach that shares decision-making with } \\
\text { stakeholders in the evaluation of a program or service in } \\
\text { some point of the process. }\end{array}$ & $\begin{array}{l}\text { empowerment } \\
\text { evaluation; } \\
\text { participatory or } \\
\text { democratic } \\
\text { evaluation }\end{array}$ & $\begin{array}{l}\text { Cousins \& Whitmore } \\
\text { (1998); Greene } \\
\text { (2006); Whitmore } \\
\text { (1998) }\end{array}$ \\
\hline $\begin{array}{l}\text { Participatory } \\
\text { Health } \\
\text { Research } \\
\text { (PHR) }\end{array}$ & $\begin{array}{l}\text { A research paradigm that most centrally values } \\
\text { participation from stakeholders in the research process in } \\
\text { specific ways to improve the quality and relevance of the } \\
\text { research. }\end{array}$ & $\begin{array}{l}\text { community-based } \\
\text { participatory } \\
\text { research }\end{array}$ & $\begin{array}{l}\text { ICPHR (2013); } \\
\text { Ramsden, McKay, \& } \\
\text { Crowe (2010); } \\
\text { Wright \& Kongats } \\
\text { (2018) }\end{array}$ \\
\hline $\begin{array}{l}\text { Participatory } \\
\text { Rural } \\
\text { Appraisal }\end{array}$ & $\begin{array}{l}\text { An approach to community development in which rural } \\
\text { people share decision-making in the programs and policies } \\
\text { that affect them. Often used by non-governmental } \\
\text { organizations. }\end{array}$ & $\begin{array}{l}\text { rapid rural } \\
\text { appraisal }\end{array}$ & $\begin{array}{l}\text { Chambers (1994); } \\
\text { Mukherjee (1997); } \\
\text { Mosse (1994) }\end{array}$ \\
\hline $\begin{array}{l}\text { Patient- } \\
\text { Centered } \\
\text { Outcomes } \\
\text { Research }\end{array}$ & $\begin{array}{l}\text { Research investigating the outcomes that are important to } \\
\text { patients, with the rationale that clinical research is higher } \\
\text { quality when it is informed by perspectives of the end } \\
\text { users. Often used in healthcare research. }\end{array}$ & $\begin{array}{l}\text { patient-centered } \\
\text { research }\end{array}$ & $\begin{array}{l}\text { Frank, Basch, \& Selby } \\
\text { (2014); Gabriel } \\
\text { (2012); Selby, Beal \& } \\
\text { Frank (2012) }\end{array}$ \\
\hline $\begin{array}{l}\text { Popular } \\
\text { Education }\end{array}$ & $\begin{array}{l}\text { A people-oriented, people-guided approach to education } \\
\text { pioneered by Paulo Freire that centers people's life } \\
\text { experiences and sees all participants as both teacher and } \\
\text { learner. }\end{array}$ & $\begin{array}{l}\text { popular adult } \\
\text { education; critical } \\
\text { education }\end{array}$ & $\begin{array}{l}\text { Freire (2018); Giroux } \\
\text { et al (1999); Torres } \\
\text { (1992) }\end{array}$ \\
\hline $\begin{array}{l}\text { Popular } \\
\text { Epidemiology }\end{array}$ & $\begin{array}{l}\text { A research process in which lay people gather data and } \\
\text { work with experts to understand the epidemiology of } \\
\text { disease and develop treatments. }\end{array}$ & $\begin{array}{l}\text { environmental } \\
\text { justice research }\end{array}$ & Brown (1992) \\
\hline $\begin{array}{l}\text { Practitioner } \\
\text { Inquiry }\end{array}$ & $\begin{array}{l}\text { A reflective approach to professional development for } \\
\text { practitioners that involves asking research questions, } \\
\text { collecting data, evaluating inquiries, and taking action. }\end{array}$ & $\begin{array}{l}\text { practitioner action } \\
\text { research, critical } \\
\text { practitioner } \\
\text { inquiry; teacher } \\
\text { action research }\end{array}$ & $\begin{array}{l}\text { Anderson, Herr, \& } \\
\text { Nihlen (2007); } \\
\text { Cochran-Smith \& } \\
\text { Lytle (2015); } \\
\text { Coughlan (2014) }\end{array}$ \\
\hline $\begin{array}{l}\text { Pragmatic } \\
\text { Action } \\
\text { Research }\end{array}$ & $\begin{array}{l}\text { A cyclical progression of action research and collaborative } \\
\text { evaluation designed to enhance co-generative learning } \\
\text { among the participants with the end goal of solving } \\
\text { problems. }\end{array}$ & $\begin{array}{l}\text { co-generative } \\
\text { research }\end{array}$ & $\begin{array}{l}\text { Greenwood (2014); } \\
\text { Greenwood (2007) }\end{array}$ \\
\hline Team Science & $\begin{array}{l}\text { Collaborative, cross-disciplinary approaches to complex } \\
\text { social problems that have many causes (e.g., climate } \\
\text { change, chronic disease). }\end{array}$ & $\begin{array}{l}\text { interdisciplinary } \\
\text { team science }\end{array}$ & $\begin{array}{l}\text { National Research } \\
\text { Council (2015); } \\
\text { Stokols, Hall, Taylor, } \\
\& \text { Moser (2008) }\end{array}$ \\
\hline $\begin{array}{l}\text { User- } \\
\text { Centered } \\
\text { Design } \\
\text { Research }\end{array}$ & $\begin{array}{l}\text { An iterative design process that involves users in the } \\
\text { design of products or services that are intended for them. }\end{array}$ & $\begin{array}{l}\text { design thinking; } \\
\text { PostDesign; } \\
\text { participatory } \\
\text { design research; } \\
\text { human-centered } \\
\text { design }\end{array}$ & $\begin{array}{l}\text { Mao, Vredenburg, } \\
\text { Smith \& Carey } \\
\text { (2005); Sanders } \\
(2002)\end{array}$ \\
\hline
\end{tabular}


making and mutual learning. Thus, we define research methods broadly to include those concrete tools, techniques and processes used throughout the entire research process not just at the point of data collection. For instance, a particular method could be developed or adapted for use when forming a research partnership or to co-design research questions. Furthermore, research methods can include the processes and techniques for data collection, data analysis and interpretation, dissemination, and enacting change.

\section{Participatory Research Methods}

In contrast to more traditional research design strategies, researchers utilizing a PR approach often choose research methods and tools that can be conducted in a participatory, democratic manner. The foundational premise of participatory research methods is the value placed on genuine and meaningful participation - methods that offer "the ability to speak up, to participate, to experience oneself and be experienced as a person with the right to express yourself and to have the expression valued by others" (Abma et al., 2019, p. 127). The ways in which stakeholders participate will vary at each step of the research process, and there are infinite options as to how to share decision making in each research task. Figure 1 depicts "choice points" - the intersection between participation and steps in the research cycle. During each and all phases of research, decisions must be made about which tools and methods will produce the desired level of participation. First, stakeholders must identify their needs and goals of the research process. Second, researchers must identify the fundamental needs of research to provide the desired evidence, outcome, or impact. Ideally, academic-community partnerships will work together to make choices that will best meet the needs of both the research and those involved in the research. These choices might lead to highly participatory strategies for some steps in the research process, and more researcher-driven strategies at others. For example, an academic-community partnership focused on environmental justice might use a citizen science approach to collect soil samples, interpret results in the context of local environments, and disseminate results back into the community. In contrast, the partnership might decide that researchers have the equipment, skills, and tools to analyze the soil samples so the data analysis stage will be conducted by the researchers. Figure 1 emphasizes a foundational principle of participatory research methods - there is no prescription for the "right" way to do PR; instead, research partners must collaborate to prioritize what's most important and choose methods that best represent stakeholder interests and maximize the potential for real-world impact.

Two important considerations should be made when conceptualizing choice points in participatory research design, or instances where choices about level of participation must be made. First, research tools and methods can vary in the degree of participation. The "inform" level of participation is usually associated with traditional research outreach, but could be more participatory if stakeholders ask to be informed about a particular topic. Traditional focus groups often function at the "consult" level of participation described in the 


\section{Participation Choice Points in the Research Process}

At each step in the research process, there is a choice about the degree of participation. The choice guides the selection of research methods and tools.

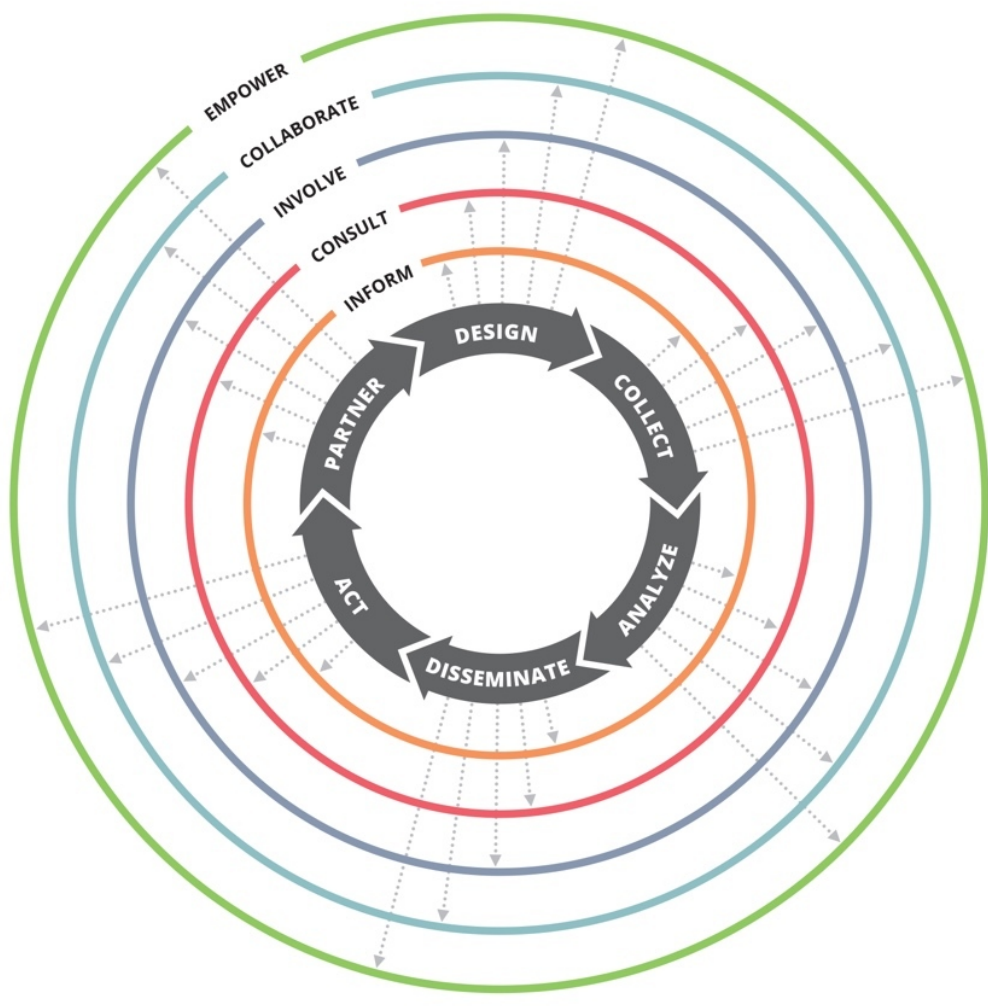

INFORM

Information is provided

to community

CONSULT

Input is obtained from

community

INVOLVE

Researchers work directly

with community

COLLABORATE

Community is partner

in research process

EMPOWER

Community leads research

decisionmaking

Levels of participation based on:

Spectrum of Public Participation

() International Association for
Public Participation www.iap2.org

Figure 1. Participation choice points in the research process.

Figure 1, with stakeholders providing feedback that researchers consider when making their research decisions. Community Advisory Boards tend to operate on the "involve" level, with community members providing feedback throughout the research process. At the "collaborate" and "empower" levels of participation, a decision to work with non-academic co-researchers would indicate a choice of research methods, tools and processes that prioritize shared decision making and co-leadership in their very structure. For example, a project that partners directly with residents of a neighborhood and trains them to be co-researchers in a project that benefits the local community could exemplify the "collaborate" level. If these residents truly led the decision making throughout the research process, this project would be functioning at the "empower" level. Notably, the potential for immediate and sustainable impact and social change are thought to rise with increasing stakeholder participation in the research process (CTSA 2011; IAP2 2018).

Second, although there are many methods and tools that are participatory by design, more conventional research methods used in quantitative and qualitative research like surveys and focus groups are not off the table. Rather, they can 
be adapted and re-thought so they are approached in a participatory way. For instance, focus groups can be co-designed, co-facilitated, and collaboratively analyzed by community co-investigators (see for example, Johnson \& Martínez Guzmán, 2013; McElfish et al., 2016). Other research partnerships have collaboratively developed and administered surveys as part of a community needs assessment (e.g., Goodman et al., 2014) or worked with community coresearchers to develop questions and conduct qualitative interviews (Watson \& Marciano, 2015). The distinguishing feature of participatory research is stakeholder power in decision making and implementation; therefore, any research method or tool can be participatory if chosen and/or utilized collaboratively between academic and community partners.

Collaborative researchers have many points throughout the research process that require choices about which method will provide the desired results, in terms of both research evidence and community impact. The participatory research literature provides rich and diverse examples to help guide partnerships through these choice points. Figure 2 contains examples of participatory research methods and tools that have been used at various steps in the research process. Researchers new to participatory research might use this figure to identify examples of the type of participatory tools that can be used for various research tasks. For example, if a partnership is looking for concrete strategies to involve community members in analyzing data, they might look to Jackson's (2008) work with marginalized women to analyze qualitative data, Main and colleagues (2012) data collection, analysis, and dissemination of health data in urban Denver neighborhoods, or Cashman and colleagues (2008) overview of four public health case studies that involved stakeholders in data analysis and interpretation. Although the results of participatory research are prolific in the literature, it can be difficult to isolate concrete descriptions of how the research was collaboratively conducted. We offer these examples as a starting point to inspire future use of participatory research methods and tools.

\section{Conclusion}

The focus on participatory research methods is necessary to truly actualize the dual goals of PR: knowledge production and real-world action conducted in a democratic, collaborative manner. A deliberate choice of participatory research methods can help researchers more deeply engage stakeholders and communities at each step of the research process. Such engagement allows research to benefit from the collective wisdom of both researchers and communities which in turn creates more meaningful findings translated to action. Researchers across many disciplines have a long history of working with non-academic stakeholders in PR, but the nuts-and-bolts description of how to do this work is often minimal to non-existent. Explicit description of the participatory research methods, tools, and processes along with documentation of the challenges and facilitators to implementation will strengthen PR and broaden its impact. 


\section{Example participatory research methods/tools for each step in the research process}

\begin{tabular}{|c|c|}
\hline Steps in the Research Process & Example Participatory Research Methods/Tools \\
\hline $\begin{array}{l}\text { PARTNER } \\
\text { - Develop a research partnership } \\
\text { - Build relationships } \\
\text { - Evaluate and sustain partnership }\end{array}$ & $\begin{array}{l}\text { Warm calling (Lapierre et al., 2018) } \\
\text { Stone soup (Ndulue et al., 2012) } \\
\text { Boundary crossers/co-researchers (Kilpatrick et al., 2009) } \\
\text { Community advisory boards (Newman et al., 2011) } \\
\text { Synergy model (Brush, Baiardi, \& Lapides, 2011) }\end{array}$ \\
\hline $\begin{array}{l}\text { DESIGN } \\
\text { - Develop research questions } \\
\text { - Plan research design }\end{array}$ & $\begin{array}{l}\text { Action learning sets (Munns et al., 2017) } \\
\text { Storytelling group (Kankainen et al., 2012) }\end{array}$ \\
\hline $\begin{array}{l}\text { COLLECT } \\
\text { - Assessment of community needs, } \\
\text { resources, and priorities } \\
\text { - Data collection } \\
\text { - Idea generation }\end{array}$ & $\begin{array}{l}\text { Community risk assessment (Van Aalst, Cannon, \& Burton, 2008) } \\
\text { Group Level Assessment (Vaughn et al., 2011) } \\
\text { Concept mapping methodology (Vaughn et al., 2016) } \\
\text { Arts-based, co-created fotonovelas (Hidalgo, 2015) } \\
\text { Narrative workshops (Lykes \& Crosby, 2014) }\end{array}$ \\
\hline $\begin{array}{l}\text { ANALYZE } \\
\text { - Data analysis } \\
\text { - Data interpretation }\end{array}$ & $\begin{array}{l}\text { Participatory group process for data analysis (Jackson, 2008) } \\
\text { Community-based participatory data system (Main et al., 2012) } \\
\text { Participatory data analysis and interpretation (Cashman et al., } \\
\text { 2008) }\end{array}$ \\
\hline $\begin{array}{l}\text { DISSEMINATE } \\
\text { - Telling and showing } \\
\text { - Dissemination }\end{array}$ & $\begin{array}{l}\text { Decision guide (Van Eerd et al., 2016) } \\
\text { Collaborative GIS tool (Driedger et al., 2007) } \\
\text { Ethnodrama (Taylor et al., 2017) }\end{array}$ \\
\hline $\begin{array}{l}\text { ACT } \\
\text { - Enacting change } \\
\text { - Sharing impact of project } \\
\text { - Policy-level outcomes }\end{array}$ & $\begin{array}{l}\text { Urban community action planning (Ross \& Coleman, 2000) } \\
\text { Participatory forecasting (Gudowsky et al., 2012) } \\
\text { Participatory monitoring and evaluation (Holte-McKenzie, } \\
\text { Forde \& Theobald, 2006) } \\
\text { Framework to Assess the Impact from Translational health } \\
\text { research (FAIT; Searles et al., 2016) }\end{array}$ \\
\hline
\end{tabular}

Figure 2. Example participatory research methods for each step in the research process. 


\section{References}

Abma, T., Banks, S., Cook, T., Dias, S., Madsen, W., Springett, J., \& Wright, M. T. (2019). Participatory research for health and social well-being. Springer.

Ahmed, S. M., \& Palermo, A.-G. S. (2010). Community engagement in research: Frameworks for education and peer review. American Journal of Public Health, 100(8), 1380-1387. https://doi.org/ 10.2105/ajph.2009.178137

Anderson, G., Herr, K., \& Nihlen, A. (2007). Studying your own school: An educator's guide to practitioner action research. Corwin Press. https://doi.org/10.4135/9781483329574

Argyris, C., Putnam, R., \& Smith, D. (1985). Action science: Concepts, methods and skills for research and intervention. Jossey-Bass.

Argyris, Chris. (1995). Action science and organizational learning. Journal of Managerial Psychology, 10(6), 20-26. https://doi.org/10.1108/02683949510093849

Balazs, C. L., \& Morello-Frosch, R. (2013). The three Rs: How community-based participatory research strengthens the rigor, relevance, and reach of science. Environmental Justice, 6(1), 9-16. https://doi.org/10.1089/env.2012.0017

Baum, F., MacDougall, C., \& Smith, D. (2006). Participatory action research. Journal of Epidemiology E' Community Health, 60(10), 854-857. https://doi.org/10.1136/jech.2004.028662

Bennett, J. W. (1996). Applied and Action Anthropology: Ideological and Conceptual Aspects. Current Antbropology, 37(S1), S23-S53. https://doi.org/10.1086/204461

Bonney, R., Cooper, C. B., Dickinson, J., Kelling, S., Phillips, T., Rosenberg, K. V., \& Shirk, J. (2009). Citizen science: A developing tool for expanding science knowledge and scientific literacy. BioScience, 59(11), 977-984. https://doi.org/10.1525/bio.2009.59.11.9

Bradbury, H. (Ed.). (2015). The Sage handbook of action research. SAGE Publications. https://doi.org/ $\underline{10.4135 / 9781473921290}$

Briggs, D. J. (2008). A framework for integrated environmental health impact assessment of systemic risks: A review. Environmental Health, 7(1), 61-78. https://doi.org/10.1186/1476-069x-7-61

Brown, P. (1992). Popular epidemiology and toxic waste contamination: Lay and professional ways of knowing. Journal of Health and Social Behavior, 33(3), 267. https://doi.org/10.2307/2137356

Busch, M. D., Jean-Baptiste, E., Person, P. F., \& Vaughn, L. M. (2019). Activating social change together: A qualitative synthesis of collaborative change research, evaluation and design literature. Gateways: International Journal of Community Research and Engagement, 12(2). https://doi.org/ 10.5130/ijcre.v12i2.6693

Bush, P. L., Pluye, P., Loignon, C., Granikov, V., Wright, M. T., Pelletier, J.-F., Bartlett-Esquilant, G., Macaulay, A. C., Haggerty, J., Parry, S., \& Repchinsky, C. (2017). Organizational participatory research: A systematic mixed studies review exposing its extra benefits and the key factors associated with them. Implementation Science, 12(1). https://doi.org/10.1186/s13012-017-0648-y

Cammarota, J., \& Fine, M. (Eds.). (2010). Revolutionizing education: Youth participatory action research in motion. Routledge. https://doi.org/10.4324/9780203932100

Cargo, M., \& Mercer, S. L. (2008). The value and challenges of participatory research: Strengthening its practice. Annual Review of Public Health, 29(1), 325-350. https://doi.org/10.1146/ annurev.publhealth.29.091307.083824

Cashman, S. B., Adeky, S., Allen III, A. J., Corburn, J., Israel, B. A., Montaño, J., Rafelito, A., Rhodes, S. D., Swanston, S., Wallerstein, N., \& Eng, E. (2008). The power and the promise: Working with communities to analyze data, interpret findings, and get to outcomes. American Journal of Public Health, 98(8), 1407-1417. https://doi.org/10.2105/ajph.2007.113571 
Chambers, R. (1994). The origins and practice of participatory rural appraisal. World Development, 22(7), 953-969. https://doi.org/10.1016/0305-750x(94)90141-4

Chandler, D., \& Torbert, B. (2003). Transforming inquiry and action: Interweaving 27 flavors of action research. Action Research, 1(2), 133-152. https://doi.org/10.1177/14767503030012002

Chevalier, J. M., \& Buckles, D. J. (2019). Participatory action research: Theory and methods for engaged inquiry (2nd ed.). Routledge. https://doi.org/10.4324/9781351033268

Chilisa, B. (2019). Indigenous research methodologies. Sage Publications.

Chinman, M., Hannah, G., Wandersman, A., Ebener, P., Hunter, S. B., Imm, P., \& Sheldon, J. (2005). Developing a community science research agenda for building community capacity for effective preventive interventions. American Journal of Community Psychology, 35(3-4), 143-157. https://doi.org/10.1007/s10464-005-3390-6

Cochran-Smith, M., \& Lytle, S. L. (2015). Inquiry as stance: Practitioner research for the next generation. Teachers College Press.

Cooperrider, D., Whitney, D. D., Stavros, J. M., \& Stavros, J. (2008). The appreciative inquiry handbook: For leaders of change. Berrett-Koehler Publishers.

Cornwall, A., \& Jewkes, R. (1995). What is participatory research? Social Science $\underbrace{\circ}$ Medicine, 41(12), 1667-1676. https://doi.org/10.1016/0277-9536(95)00127-s

Coughlan, D. (2014). Doing action research in your own organization. Sage Publications.

Cousins, J. B., \& Whitmore, E. (1998). Framing participatory evaluation. New Directions for Evaluation, 1998(80), 5-23. https://doi.org/10.1002/ev.1114

CTSA Community Engagement Key Function Committee Task Force on the Principles of Community Engagement. (2011). Principles of Community Engagement, 2nd edition. National Institutes of Health.

Dickinson, J. L., Shirk, J., Bonter, D., Bonney, R., Crain, R. L., Martin, J., Phillips, T., \& Purcell, K. (2012). The current state of citizen science as a tool for ecological research and public engagement. Frontiers in Ecology and the Environment, 10(6), 291-297. https://doi.org/10.1890/110236

Frank, L., Basch, E., Selby, J. V., \& For the Patient-Centered Outcomes Research Institute. (2014). The PCORI Perspective on Patient-Centered Outcomes Research.JAMA, 312(15), 1513. https://doi.org/10.1001/jama.2014.11100

Freire, P. (2018). Pedagogy of the oppressed (50th anniversary). Bloomsbury Publishing.

Friedman, V., Razer, M., \& Sykes, I. (2004). Towards a theory of inclusive practice: An action science approach. Action Research, 2(2), 167-189. https://doi.org/10.1177/1476750304043729

Gabriel, S. E., \& Normand, S.-L. (2012). Getting the methods right - the foundation of patientcentered outcomes research. New England Journal of Medicine, 367(9), 787-790. https://doi.org/ 10.1056/nejmp1207437

Giroux, H. A., Flecha, R., Freire, P., Macedo, D., \& Castells, M. (1999). Critical education in the new information age. Rowman \& Littlefield Publishers.

Goodman, M. S., Gonzalez, M., Gil, S., Si, X., Pashoukos, J. L., Stafford, J. D., Ford, E., \& Pashoukos, D. A. (2014). Brentwood community health care assessment. Progress in Community Health Partnerships: Research, Education, and Action, 8(1), 5-6. https://doi.org/10.1353/cpr.2014.0012

Greene, J. C. (2006). Evaluation, democracy, and social change. In I. F. Shaw, J. C. Greene, \& M. M. Park (Eds.), The Sage handbook of evaluation (pp. 118-140). Sage Publications.

Greenwood, D. (2007). Pragmatic action research. International Journal of Action Research, 3(1+2), 131-148.

Greenwood, D. J. (2014). Pragmatic action research. In M. Brydon-Miller \& D. Coghlan (Eds.), The Sage encyclopedia of action research (pp. 644-647). Sage Publications. 
International Association of Public Participation (IAP2). (2018). IAP2 Spectrum of Public

Participation. https://cdn.ymaws.com/www.iap2.org/resource/resmgr/pillars/

Spectrum_8.5x11_Print.pdf

International Collaboration for Participatory Health Research (ICPHR). (2013). Position Paper 1: What is Participatory Health Research? http://www.icphr.org/uploads/2/0/3/9/20399575/ ichpr_position_paper_1_defintion_-_version_may_2013.pdf

Israel, B. A., Eng, E., Schulz, A. J., \& Parker, E. A. (2013). Introduction to methods for CBPR for health. In B. A. Israel, E. Eng, A. J. Schulz, \& E. A. Parker (Eds.), Methods for community-based participatory research for health (pp. 3-38). John Wiley \& Sons, Inc.

Jagosh, J., Macaulay, A. C., Pluye, P., Salsberg, J., Bush, P. L., Henderson, J., Sirett, E., Wong, G., Cargo, M., Herbert, C. P., Seifer, S. D., Green, L. W., \& Greenhalgh, T. (2012). Uncovering the benefits of participatory research: Implications of a realist review for health research and practice. Milbank Quarterly, 90(2), 311-346. https://doi.org/10.1111/j.1468-0009.2012.00665.x

Johnson, K., \& Martínez Guzmán, A. (2013). Rethinking concepts in participatory action research and their potential for social transformation: Post-structuralist informed methodological reflections from LGBT and trans-collective projects. Journal of Community $\sigma^{2}$ Applied Social Psychology, 23(5), 405-419. https://doi.org/10.1002/casp.2134

Key, K. D., Furr-Holden, D., Lewis, E. Y., Cunningham, R., Zimmerman, M. A., Johnson-Lawrence, V., \& Selig, S. (2019). The Continuum of Community Engagement in Research: A Roadmap for Understanding and Assessing Progress. Progress in Community Health Partnerships: Research, Education, and Action, 13(4), 427-434. https://doi.org/10.1353/cpr.2019.0064

Kinsler, K. (2010). The utility of educational action research for emancipatory change. Action Research, 8(2), 171-189. https://doi.org/10.1177/1476750309351357

Kretzmann, J., \& McKnight, J. P. (1996). Assets-based community development. National Civic Review, 85(4), 23-29. https://doi.org/10.1002/ncr.4100850405

Lewin, K. (1946). Action research and minority problems. Journal of Social Issues, 2(4), 34-46. https://doi.org/10.1111/j.1540-4560.1946.tb02295.x

Lock, K. (2000). Health impact assessment. BMJ, 320(7246), 1395-1398. https://doi.org/10.1136/ bmj.320.7246.1395

Luke, D. A. (2005). Getting the big picture in community science: Methods that capture context. American Journal of Community Psychology, 35(3-4), 185-200. https://doi.org/10.1007/ $\underline{\text { s10464-005-3397-z }}$

Main, D. S., Ware, G., Iwasaki, P. G., Burry, M., Steiner, E., Fedde, K., \& Haverhals, L. M. (2012). Taking Neighborhood Health to Heart (TNH2H): Building a community-based participatory data system. Preventing Chronic Disease, 9, E41. https://doi.org/10.5888/pcd9.110058

Mao, J.-Y., Vredenburg, K., Smith, P. W., \& Carey, T. (2005). The state of user-centered design practice - UCD is gaining industry acceptance - but its current practice needs fine-tuning. Communications of the ACM, 48(3), 105-109. https://doi.org/10.1145/1047671.1047677

Mathie, A., \& Cunningham, G. (2003). From clients to citizens: Asset-based community development as a strategy for community-driven development. Development in Practice, 13(5), 474-486. https://doi.org/10.1080/0961452032000125857

McElfish, P. A., Purvis, R. S., Maskarinec, G. G., Bing, W. I., Jacob, C. J., Ritok-Lakien, M., RubonChutaro, J., Lang, S., Mamis, S., \& Riklon, S. (2016). Interpretive policy analysis: Marshallese COFA migrants and the Affordable Care Act. International Journal for Equity in Health, 15(1). https://doi.org/10.1186/s12939-016-0381-1 
McGill, I., \& Brockbank, A. (2003). The Action Learning Handbook. Routledge. https://doi.org/ $\underline{10.4324 / 9780203416334}$

Mertler, C. A. (Ed.). (2019). The Wiley handbook of action research in education. John Wiley \& Sons, Inc. https://doi.org/10.1002/9781119399490

Mosse, D. (1994). Authority, Gender and Knowledge: Theoretical Reflections on the Practice of Participatory Rural Appraisal. Development and Change, 25(3), 497-526. https://doi.org/10.1111/ j.1467-7660.1994.tb00524.x

Mukherjee, N. (1997). Participatory rural appraisal (Vol. 1). Concept Publishing Company.

National Research Council. (2015). Enhancing the effectiveness of team science. National Academies Press. https://doi.org/10.17226/19007

Oliver, M. (1997). Emancipatory research: Realistic goal or impossible dream. Doing Disability Research, 2, 15-31.

Ozer, E. J. (2017). Youth-Led Participatory Action Research: Overview and Potential for Enhancing Adolescent Development. Child Development Perspectives, 11(3), 173-177. https://doi.org/ $\underline{10.1111 / \text { cdep. } 12228}$

Ramsden, V. R., McKay, S., \& Crowe, J. (2010). The pursuit of excellence: Engaging the community in participatory health research. Global Health Promotion, 17(4), 32-42. https://doi.org/10.1177/ $\underline{1757975910383929}$

Reason, P., \& Torbert, W. (2001). The action turn: Toward a transformational social science. Concepts and Transformation International Journal of Action Research and Organizational Renewal, 6(1), 1-37. https://doi.org/10.1075/cat.6.1.02rea

Reed, J. (2007). Appreciative inquiry: Research for change. SAGE Publications, Inc. https://doi.org/ $\underline{10.4135 / 9781412983464}$

Revans, R. W. (2011). ABC of Action Learning. Gower Publishing, Ltd.

Sanders, E. B.-N. (2002). From user-centered to participatory design approaches. In J. Frascara (Ed.), Design and the social sciences (pp. 18-25). CRC Press.

Selby, J. V., Beal, A. C., \& Frank, L. (2012). The Patient-Centered Outcomes Research Institute (PCORI) national priorities for research and initial research agenda.JAMA, 307(15), 1583. https://doi.org/10.1001/jama.2012.500

Shirk, J. L., Ballard, H. L., Wilderman, C. C., Phillips, T., Wiggins, A., Jordan, R., McCallie, E., Minarchek, M., Lewenstein, B. V., Krasny, M. E., \& Bonney, R. (2012). Public participation in scientific research: A framework for deliberate design. Ecology and Society, 17(2). https://doi.org/ 10.5751/es-04705-170229

Smith, L. T. (2013). Decolonizing methodologies: Research and indigenous peoples. Zed Books Ltd. Somekh, B. (2009). The Sage handbook of educational action research. Sage Publications.

Stokols, D., Hall, K. L., Taylor, B. K., \& Moser, R. P. (2008). The science of team science: Overview of the field and introduction to the supplement. American Journal of Preventive Medicine, 35(2), S77-S89. https://doi.org/10.1016/j.amepre.2008.05.002

Stull, D. D. (2019). Collaborative research and social change: Applied anthropology in action: Routledge (D. D. Stull \& J. J. Schensul, Eds.). Routledge. https://doi.org/10.4324/9780429040573

Suzanne F. Jackson. (2008). A participatory group process to analyze qualitative data. Progress in Community Health Partnerships: Research, Education, and Action, 2(2), 161-170. https://doi.org/ 10.1353/cpr.0.0010

Tax, S. (1975). Action anthropology. Current Anthropology, 16(4), 514-517. https://doi.org/10.1086/ $\underline{201616}$ 
Torbert, W. R. (2004). Action inquiry: The secret of timely and transforming leadership. BerrettKoehler Publishers.

Torres, C. A. (1992). Participatory action research and popular education in Latin America. International Journal of Qualitative Studies in Education, 5(1), 51-62. https://doi.org/10.1080/ $\underline{0951839920050107}$

Vaughn, L. M., Whetstone, C., Boards, A., Busch, M. D., Magnusson, M., \& Määttä, S. (2018). Partnering with insiders: A review of peer models across community-engaged research, education and social care. Health E'Social Care in the Community, 26(6), 769-786. https://doi.org/10.1111/ hsc. 12562

Wallerstein, N. B., \& Duran, B. (2006). Using community-based participatory research to address health disparities. Health Promotion Practice, 7(3), 312-323. https://doi.org/10.1177/ $\underline{1524839906289376}$

Wallerstein, N., Duran, B., Oetzel, J., \& Minkler, M. (Eds.). (2018). Community-based participatory research for health: Advancing social and health equity (3rd ed.). Jossey-Bass.

Walmsley, J. (2001). Normalisation, emancipatory research and inclusive research in learning disability. Disability E'Society, 16(2), 187-205. https://doi.org/10.1080/09687590120035807

Wandersman, A. (2003). Community Science: Bridging the Gap between Science and Practice with Community-Centered Models. American Journal of Community Psychology, 31(3-4), 227-242. https://doi.org/10.1023/a:1023954503247

Warren, M. R., Calderón, J., Kupscznk, L. A., Squires, G., \& Su, C. (2018). Is Collaborative, Community-Engaged Scholarship More Rigorous Than Traditional Scholarship? On Advocacy, Bias, and Social Science Research. Urban Education, 53(4), 445-472. https://doi.org/10.1177/ $\underline{0042085918763511}$

Watkins, J. M., Mohr, B., \& Kelly, R. (2011). Appreciative inquiry: Change at the speed of imagination (2nd ed.). Pfeiffer. https://doi.org/10.1002/9781118256060

Watson, V. W. M., \& Marciano, J. E. (2015). Examining a social-participatory youth co-researcher methodology: A cross-case analysis extending possibilities of literacy and research. Literacy, 49(1), 37-44. https://doi.org/10.1111/lit.12053

Whitmore, E. (1998). Understanding and practicing participatory evaluation. New Directions for Evaluation, 80, 1-104. https://doi.org/10.1002/ev.1113

Wright, M. T., \& Kongats, K. (Eds.). (2018). Participatory health research: Voices from around the world. Springer.

Zuber-Skerritt, O., Wood, L., \& Kearney, J. (2020). The transformative potential of action learning in community-based research for social action. Action Learning: Research and Practice, 17(1), 34-47. https://doi.org/10.1080/14767333.2020.1712840 